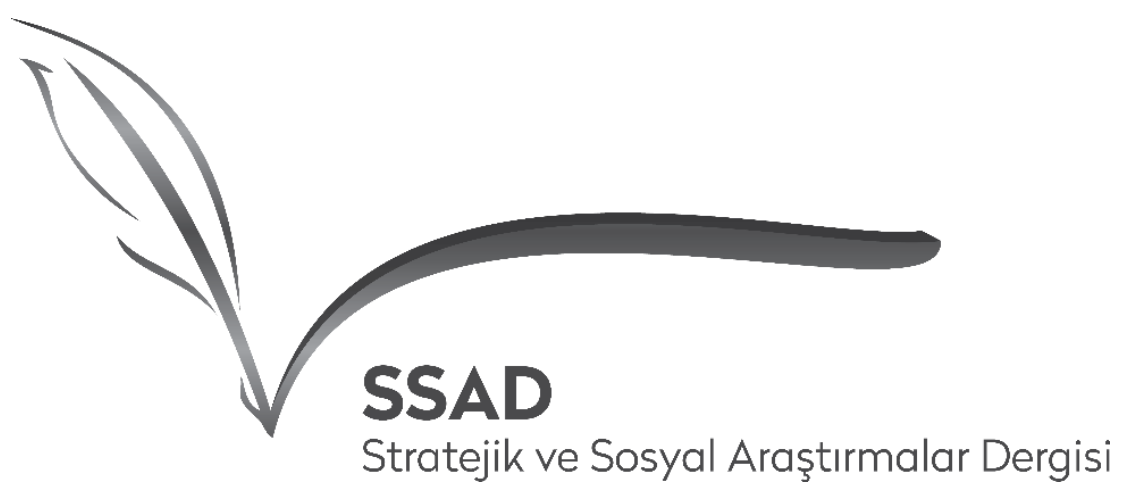

ISSN: $2587-2621$

Volume 2 Issue 2, July 2018

\title{
PERCEPTION ABOUT ACADEMICS IN TURKEY: THE POWER OF ANONYMITY
}

\section{Türkiye’de Akademisyen Algısı: Anonimliğin Gücü}

\author{
Cihan SERDAROĞLU* \\ R. Özgün KEHYA**
}

Öz: Bu makale, oldukça popüler olan bir web site (eksisozluk.com) aracıllı̆ıyla Türkiye'deki akademisyen algısını analiz etmektedir. Makale, bu sitede akademisyenlerle ilgili yorumları sistematik bir analiz yoluyla tanımlama ve çözümlemeyi içermektedir. Çalışma için eksisozluk.com, kişiler burada anonim olarak yazabildikleri ve böylece, genellikle yüz yüzeyken söyleyemedikleri șeyleri rahatça söyleyebildikleri için seçilmiștir. Siteye baktığımız zaman, akademisyen kelimesiyle ilgili en üstte yer alan sekiz başlık ve her bir başlıkla ilgili de yüzlerce yorum yer aldığını görüyoruz. Çalışma için bu sekiz başlıktan her birinin içerdiği yorumlardan ellişer tanesi, toplamda ise dört yüz yorum analiz edilmiştir. Yorumların analizinde içerik analizi tekniği kullanılmıştır ve araştırma bulguları, Türkiye'de akademisyenlerle ilgili oldukça yüksek düzeyde olumsuz bir algı olduğunu göstermektedir.

Anahtar Sözcükler: Akademisyen Algıs1, Akademisyenlerle İlgili Yorumlar, Yeni Medya, Sosyal Medya, Anonimlik.

Abstract: This article analyzes perception about academics in Turkey through a very popular website (eksisozluk.com). The article employs systematic analysis to identify and analyze comments about academics in the website. Eksisozluk.com is chosen because people can anonymously write on there; therefore they can tell something which generally cannot be said face to face. When we looked at the site, we saw top eight titles about academics and there are hundreds of comments for each entry. We have analyzed fifty of comments for each entry which makes four hundred of comments in total. The comments are analyzed by the method of content analysis and the results affirm there is a high negative perception about academics in Turkey.

Keywords: Perception about Academics, Comments about Academics, New Media, Social Media, Anonymity.

\footnotetext{
* Ankara Üniversitesi, İletişim Fakültesi, Gazetecilik Bölümü Doktora Öğrencisi, cihanserdar@windowslive.com

** Arş. Gör. Kafkas Üniversitesi, ozgunkehya@gmail.com
} 


\section{Introduction}

In Turkey, one can see that university students and graduates generally complain about academics like "they have big egos, they are not good enough for academy, they do not care about students, they do not respond even e-mails, they don't speak good English etc." and unfortunately, the list goes on, and when we take a look at literature on perception about academics, we cannot find papers about it. Therefore, we have decided to conduct a research on perception about academics in Turkey.

The importance of current research is to can give us a relatively general idea on perception about academics in Turkey; therefore, we are going to have a scientific research on perception about academics, and may be, academics who live in Turkey, can realize their negative behaviors and chance them in a positive way. Briefly, those are the academical and practical benefits of this research. As we have mentioned before, there is no paper on perception about academics in international and national field, and the subject can not take a part in news, thus we can not give example articles or news about the topic.

The intention of current paper is to demonstrate the general perception about academics in Turkey on a very famous site Ekşi Sözlük (https://eksisozluk.com/) which is a social media platform containing anonymous user generated content to a large extent. The reason we have chosen this site for the research is that we believe in power of anonymity, because people can easily say something without hiding in this way, and thus we can learn their "real" ideas about academics. Therefore, we can say that the reason we are doing this study, we just want to learn how is the perception about academics in Turkey.

In the research, the comments are analyzed by content analysis. The reason we have chosen this method is that gives you an opportunity to analyze so many comments.

When we looked at the site, we saw top eight titles about academics and we examined fifty of comments/entries for each of these titles we analyzed four hundred of comments in total and footnoted their links. While we made the content analysis, we created four categories as positive, negative, both including and incomprehensible/neutral and we started to analyze from the last comment for it should be new and more up-to-date. We also gave examples of people's complaints in each four category.

\section{The Concept of Academic in Turkey}

An academic is a member of an academy who teaches at a college, or who studies as part of their job to improve or maintain standards in a particular field of arts, sciences, or letters. ${ }^{1}$

An academic is a kind of knowledge worker who need to think for a living. He is a professional thinker, writer, speaker, teacher and/or researcher. Academic work involves also public lectures, conferences, publications, professional consulting, and project managements. Since academics are one of the most influential actors who are role models and shape students' future, their mission is very important both for them, students and the society. University students are highly influenced by the academics' positive or negative aspects, because they are in the period in which most open to development. ${ }^{2}$

${ }^{1}$ Cambridge Dictionary. Meaning of "academician" in the English Dictionary. http://dictionary.cambridge.org/dictionary/english/academician (accessed 07 28, 2017); Academician Definifition and Meaning /Collins Dictionary. 2010. https://www.collinsdictionary.com/dictionary/english/academician (accessed 07 28, 2017).

${ }^{2}$ Konakay, Gönül, Ali Akdemir, and Banu Ergen. "Investigation Of The Charisma And Intellectuality Effect In Determining A Leadership Model In The Light Of University Students' Interaction With Their Academicians And Parents." Journal of Business Turk 1, no. 7 (2015): 212. 
Academics who work in universities and research institutions have different positions such as researching assistants, lecturers, assistant professors, associate professors, professors and professor-in-ordinary. In order to progress throughout their academic's career, it is essential to conduct research, publish articles, notes and/or books, translate scientific papers and give public lectures for academics in Turkey. These are measures of academic and research productivity in Turkey like many other countries. However according to a study, ${ }^{3}$ counting are not only the references for academic and research productivity. "As a measure of scientific impact, publication counts alone are an insufficiently descriptive reporting metric of scientific research activities for the public, physicians, scientists, academic institutions and funding agencies." Academic productivity should be also measured by effective teaching and ensuring students learn on their fields.

English knowledge is essential to make research in English language and publish academic works in international refereed books or journals and make public lectures or participate in international conferences. Therefore good level of English is both useful and prestigious for an academic. The article titled, "What counts for academic productivity in research universities?" discusses the race of publication in global higher education. ${ }^{4}$

Publication in high prestigious journals has become a major criterion for academic success in the competitive environment of global higher education. Appearing in internationally circulated journals published in English is especially prestigious. Universities are engaged in a global arms race of publication; and academics are the shock troops of the struggle.

Moreover, for especially higher grades, it is essential to speak good level of English in Turkey. While some small universities don't require any foreign language knowledge at lower grade jobs such as researching, it is necessary to have a certain level of English knowledge in studying doctorate degree or become assistant professor. The highly favorable universities such as Ankara University or Hacettepe University require English language even for acceptance to master degree programs and/or for becoming a researcher. For that reason, English knowledge is very important for academics.

According to an article titled "Why Professors Are Writing Crap That Nobody Reads", 5 academics write articles for job security and money, 82 percent of articles published in the humanities are not even cited once and half of academic papers are never read by anyone other than their authors, peer reviewers, and journal editors. Creative plagiarism and rearrangements of previous research or repeating information with a new thesis are some problems in academic papers.

According to the research "Working Life in Turkey and Reputation of Professions" the job of researching assistant at universities is at the 18th and being a professor at universities is at the 2nd rate in most reputable jobs list. It was determined in the survey that the first three characteristics of the most important features in a good job were a good salary, a job guarantee and job security ${ }^{6}$.

\section{Anonymity}

David Davenport says that: "Anonymous communication is seen as the cornerstone of an Internet culture that promotes sharing and free speech and is overtly anti-establishment" ${ }^{\text {" }}$. Anonymity can

\footnotetext{
${ }^{3}$ Sarli, Cathy C., and Christopher R. Carpenter. "An overview of measuring academic productivity and changing definitions of scientific impact." Missouri Medicine, 2014: 401.

${ }^{4}$ Altbach, Philip G. What counts for academic productivity in research universities? 07 18, 2014.

http://www.universityworldnews.com/article.php?story=20140715105656393 (accessed 08 09, 2017).

${ }^{5}$ Lattier, Daniel. Why Professors Are Writing Crap That Nobody Reads. 10 26, 2016.

http://www.intellectualtakeout.org/blog/why-professors-are-writing-crap-nobody-reads (accessed 08 10, 2017).

${ }^{6}$ Türkiye'deki en itibarlı meslekler açıklandı. 02 16, 2017. http://www.yeniakit.com.tr/haber/turkiyedeki-en-itibarlimeslekler-aciklandi-278959.html (accessed 08 10, 2017).

${ }^{7}$ Davenport, David. "Anonymity on the internet: why the price may be too high." Communications of the Acm 45, no. 4 (April 2002): 33.
} 
ensure privacy and free speech because governments cannot spy on citizens in this way, even though there is no such a thing endless free speech despite to the anonymity.

As we have mentioned before, anonymity does not mean that one can completely hide his/her identity. "Anonymity requires all identifiable data to be removed; pseudonymity only partly hides the sender's identity." 8 and the site (eksisozluk.com) we have examined in this research is just like that too. It hides one's identity only partly. If someone thinks that is an insult for a comment, he/she can learn that person's identity and sue. For example in the year of 2014, a university student was sued because of his writing on the eksisozluk.com about a professor in Turkey, and before that he was rusticated from the university for a term. ${ }^{9}$

Nevertheless, anonymity must be something strong which is the ability to speak without anybody being able to identify you. That is how one can speak without fear of something; till a certain point. For instance, anonymity can be such an important tool for some groups or people ( people are exposure to discrimination or injustice, political dissidents, ethnic minorities, people campaigning for women's rights etc.) and thanks to anonymity, they can have a chance to write for their causes freely. Anonymity is a "safety" way for people when trust is absent or the future uncertain and we need that safety today, although this strong version of anonymity is controversial. ${ }^{10}$ Because it may cause a crime like insulting and hate speech. In this point, we can say it is a good thing that anonymity able to hide just partly one's identity, on the other hand this can block free speech. That is why, strong version of anonymity is controversial. It seems like a dilemma.

\section{About Ekșisözlük.com}

Ekşi Sözlük (www.eksisozluk.com) is a collaborative hypertext dictionary based on the concept of Web sites built up on user contribution which has published on the internet since 1999. ${ }^{11}$ Ekşi Sözlük.com is literally translated in English as "Sour Dictionary.com" and "Kutsal bilgi kaynağı" ("holy information source") is its slogan. The site describes itself as "an extended dictionary of words and terms with subjective suplies of users".

The dictionary ${ }^{12}$ recommends that certain content may not be suitable for children under 18 years of age and in parental supervision, filter software should be used. It states that the site is only place supplier and has no relation with the published content. No action is taken in the process unless a complaint is received about a published content. The site also does not have a claim that the content is correct and up-to-date in terms of use.

There are specific titles in Ekşi Sözlük so people can make search to see different user's opinion through the site. Apart from other social media platforms such as Instagram, Facebook or Twitter these sort of user generated dictionaries provide people to gather information or comment in specific title. For example Facebook, a friendship platform, people can share different content such as photos, videos and quotes etc. In this term, Facebook is more dispersed and farreaching. However eksisozluk.com is a more specialized and neat platform in term of particular discussion matters.

\footnotetext{
${ }^{8}$ Scott, Susan, and Wanda J Orlikowski. "Entanglements in Practice: Performing Anonymity Through Social Media." MIS 38, no. 3 (2014): 7.

${ }^{9}$ Yusuf Devran'a "ekşi sözlük" üzerinden hakaret ettiği belirlenen öğrenci Mikail Boz, 3 bin tl manevi tazminat. 10 17, 2014. http://www.haberturk.com/gundem/haber/1000643-dekana-hakarete-ceza (accessed 08 25, 2017).

${ }^{10}$ Froomkin, A. Michael. "From Anonymity to Identification." Journal of Self-Regulation and Regulation, SelfRegulation and Regulation 1 (2015).

${ }^{11}$ Arman, Turgut. EkşiSözlük: A Turkish Internet Phenomenon. 08 14, 2006.

http://www.hurriyetdailynews.com/h.php?news=eksi-sozluk-a-turkish-internet-phenomenon-2006-08-14 (accessed 12 12, 2010).

12 Ekşi Sözlük Kullanım Koşulları-\#19784395. 01 26, 2016. https://eksisozluk.com/entry/19784395 (accessed 08 2017, 07).
} 
As Küçükşen's article states, ${ }^{13}$ the social media platforms perform as a public sphere and people's daily/social opinions can be analyzed by content or discourse analyses. In this term, even there are user contributed similar websites such as Santral Sözlük (www.santralsozluk.com), İnci Sözlük (inci.sozlukspot.com), Uludağ Sözlük (www.uludagsozluk. com), and ITU Sözlük (www.itusozluk.com) the most popular social sharing platform the Ekşi Sözlük.com is chosen for this study. According to traffic metric provider Alexa, an estimate of this site's popularity in Turkey is 16 and 689 in globe in August 2017. ${ }^{14}$ "The rank by country is calculated using a combination of average daily visitors to this site and page views on this site from users from that country over the past month."

The site answers the generally asked questions, ${ }^{15}$ the user first sign up with a nick name entering an e-mail, date of birth, gender information. After signing up, the user must make 10 entries to be in order of approval of çaylak (Johnny-come-lately). Following the Johnny-come-lately status the user is accepted as a writer in the dictionary. As understood, that to become a writer of Ekşi Sözlük, it requires making eligible entries.

In the site, there are some channels such as agenda, today in the history, sport, relationships, politics, travel, education and music etc. When entering the word "academic" in the search section, there are 10 results for the search word such as title, entry or user. In this work, 2 of them are users and 8 of them are titles. We included the eight titles out of 10 results in the scope.

Sometimes comments on ekşisözlük.com can be in the news in traditional and new media platforms, and can cause as well as legal or criminal consequences. This site is one of the most popular social media platforms in the field, so there is a lot of news on the agenda most of which aren't discussed here because of the limitedness of the scope.

\section{The Research: Academics on Ekşi Sözlük (www.eksisozluk.com)}

When we looked at the site, we saw top eight titles about academics and we examined fifty of comments/entries for each of these titles we analyzed four hundred of comments in total and footnoted their links. While we made the content analysis, we created four categories as positive, negative, both including and incomprehensible/neutral and we started to analyze from the last comment for it should be new and more up-to-date. We also gave examples of people's complaints in each four category.

\section{The Analyses of the Titles:}

Top eight titles and the comments in each title were analyzed when typed "academic":

$1 \quad$ Academic $^{16}$

$2 \quad$ Ego of Academic ${ }^{17}$

3 The Reasons to Hate Academics ${ }^{18}$

4 Academic Arrests on15 January $2016^{19}$

\footnotetext{
${ }^{13}$ Küçükşsen, Kübra. "Perception of gender equality in new media." International Journal of Human Sciences 13, no. 1 (2016): 1286.

${ }^{14}$ Eksisozluk.com Traffic, Demographics and Competitors-Alexa. 08 08, 2017.

http://www.alexa.com/siteinfo/eksisozluk.com (accessed 08 2017, 10).

${ }^{15}$ Ekşi Sözlük Hakkında Sikça Sorulan Sorular -\#66762977 - ekşi sözlük. 03 10, 2017.

https://eksisozluk.com/entry/66762977 (accessed 07 2017, 07).

16 Turkish original translation: akademisyen

${ }^{17}$ Turkish original translation: akademisyen egosu

${ }^{18}$ Turkish original translation: akademisyenlerden nefret etme nedenleri

19 Turkish original translation: 15 ocak 2016 akademisyen gözaltıları
} 
5 Academic without $\mathrm{Ego}^{20}$

6 Turkish Style Academic ${ }^{21}$

$7 \quad$ Academic who doesn't know English ${ }^{22}$

$8 \quad$ An academic who published 270 articles in 5 years $^{23}$

- Access date: 18 July 2017

- To be more up to date last 50 entries/comments of each title analyzed. (In total 400

comments were analyzed out of 2526 comments)

- The rate of negative perception in titles $5 / 8=62 \%$ (This titles are Turkish Style Academic, An academic who published 270 articles in 5 years, The Reasons to Hate Academics, Academic who doesn't know English, Ego of Academic)

- The rate of positive perception in titles $2 / 8=25 \%$ (Academic without Ego, Academic Arrests $^{24}$ )

- The rate of neutral or unclear perception in titles $1 / 8=10 \%$ ( Academic)

\section{Negative Entries/Comments Against Academics:}

- Having big ego/ incontestable personality / cannot establishing empathy with students

- Not to reply the e-mails / Long time no see

- Plagiarism and many publishing / insufficient academic productivity

- Political connections / Being partial in the lessons in terms of politics or religion

- Rote learning / using too much PowerPoint presentations

- Falling behind the academics of other countries / being lazy / being civil servant minded / not speaking English

\section{Positive Entries Towards Academics}

*There are good academics

\section{Both Negative and Positive Entries/Comments Regarding Academics}

- Some academics are problematic; however some of them are not.

- Majority of the academics are problematic, few of them good.

- The system causes the academic problems."

- Students are problematic or lazy.

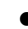

\section{Irrelevant / Incomprehensible / Neutral}

Some comments/entries consist of only one or two words. Or they are some links so it's impossible to understand in which category this is.

\footnotetext{
${ }^{20}$ Turkish original translation: egosu olmayan akademisyen

${ }^{21}$ Turkish original translation: türk tipi akademisyen

${ }^{22}$ Turkish original translation: ingilizce bilmeyen akademisyen

${ }^{23}$ Turkish original translation: 5 yılda 270 makale yazan akademisyen

24 "Academic Arrests" title can seem neutral but we take it as positive because of comments.
} 


\section{Validity and Reliability in This Research}

For validity and reliability in this research, firstly, we made an "irrelevant/incomprehensible/neutral" category, besides positive, negative and both including categories; therefore, if we are not one hundred percent sure about a comment is positive, negative or both including, we put it in this category. Secondly, we gave examples for each entry and category to show people how we did. And finally, we gave the links of the analyzed comments; in this way, if anyone want to see the comments was analyzed, he/she may look at them for seeing they are right or not. Also, we gave the first and last dates of the comments we analyzed to be clear.

\section{Table 1:}

Table according to number of total comments:

\begin{tabular}{|c|c|c|c|c|}
\hline Rank & Title $^{25}$ & $\begin{array}{l}\text { Date of } \\
\text { first } \\
\text { Title }\end{array}$ & $\begin{array}{l}\text { Number of } \\
\text { Comments }\end{array}$ & Rate \\
\hline 1 & Turkish Style Academic / N & Nov-10 & 790 & $31,27 \%$ \\
\hline 2 & $\begin{array}{l}\text { An academic who published } 270 \\
\text { articles in } 5 \text { years / } \mathrm{N}\end{array}$ & Dic-11 & 510 & $20,19 \%$ \\
\hline 3 & Academic Arrests / P & Gen-16 & 320 & $12,67 \%$ \\
\hline 4 & Academic / U or NT & Set-01 & 230 & $9,11 \%$ \\
\hline 5 & The Reasons to Hate Academics / N & Mag-15 & 220 & $8,71 \%$ \\
\hline 6 & $\begin{array}{l}\text { Academic Who doesn't know English / } \\
\mathrm{N}\end{array}$ & Ap-12 & 160 & $6,33 \%$ \\
\hline 7 & Ego of Academic / N & Mag-11 & 156 & $6,18 \%$ \\
\hline \multirow[t]{2}{*}{8} & \multirow{2}{*}{$\begin{array}{l}\text { Academic without Ego / P } \\
\text { Total }\end{array}$} & Mag-16 & 140 & $5,54 \%$ \\
\hline & & & 2526 & $100 \%$ \\
\hline
\end{tabular}

In this table abbreviation of $\mathrm{N}$ signifies Negative, $\mathrm{P}$ signifies positive and $\mathrm{U}$ signifies Unclear and NT signifies Neutral meaning.

\footnotetext{
${ }^{25}$ Here "N" means the titles carriying Negative meaning, "P" is abbrevation of Positive meaning and " $U$ " is abbrevation of unclear meaning.
} 


\section{The Analyses of the Entries/Comments}

Academic -230 Entries/Comments ${ }^{26}$

Table 2:

\begin{tabular}{|l|l|l|l|l|l|}
\hline & Positive & Negative & Both Including & $\begin{array}{l}\text { Irrelevant/ } \\
\text { Incomprehensible/ } \\
\text { Neutral }\end{array}$ & Total \\
\hline $\begin{array}{l}\text { Number of } \\
\text { comments }\end{array}$ & 5 & 22 & 10 & 13 & 50 \\
\hline Percentage & 0,1 & 0,44 & 0,2 & 0,26 & 1 \\
\hline
\end{tabular}

The first comment date: 26.09 .2015

The last comment date: 10.07.2017

Even this title was in "unclear/neutral" category, number of negative comments is high.

We can not give all comments was analyzed because they are too much and the comments are in Turkish language; that is way, it is not possible to translate for some comments, because they just give the meaning in Turkish. They do not have the same meaning in English. Although, we like to give some examples about categories as much as we can.

For example, according to one of the positive comments: "They work too much. they are hard working." For a negative comment: "They have big egos. If you ask something them, they do not answer you. If you want something from them, they snap at you." To a both including comment: "All of them are not the same. Some of them are good and some of them are bad." For a irrelevant/incomprehensible/neutral comment: "There is a book about their difficult life."

$$
\text { Ego of Academic - } 156 \text { Entries/Comments }{ }^{27}
$$

Table 3:

\begin{tabular}{|l|l|l|l|l|l|}
\hline & Positive & Negative & Both Including & $\begin{array}{l}\text { Irrelevant/ } \\
\text { Incomprehensible/ } \\
\text { Neutral }\end{array}$ & Total \\
\hline $\begin{array}{l}\text { Number of } \\
\text { comments }\end{array}$ & 4 & 21 & 19 & 6 & 50 \\
\hline Percentage & 0,08 & 0,42 & 0,38 & 0,12 & \\
\hline
\end{tabular}

The first comment date: 06.06.2017

\footnotetext{
${ }^{26}$ The links of the analyzed comments are following: https://eksisozluk.com/akademisyen--136788? $\mathrm{p}=22$ https://eksisozluk.com/akademisyen--136788? $\mathrm{p}=21$ https://eksisozluk.com/akademisyen--136788? $\mathrm{p}=20$ https://eksisozluk.com/akademisyen--136788? $\mathrm{p}=19$ https://eksisozluk.com/akademisyen--136788? $\mathrm{p}=18$ 27 The links of the analyzed comments are following: https://eksisozluk.com/akademisyen-egosu--2800975? p=18 https://eksisozluk.com/akademisyen-egosu--2800975? $\mathrm{p}=17$ https://eksisozluk.com/akademisyen-egosu--2800975? p=16 https://eksisozluk.com/akademisyen-egosu--2800975? $\mathrm{p}=15$ https://eksisozluk.com/akademisyen-egosu--2800975?p=14
} 
The last comment date: 27.07.2017

This title shows that there is a perception about academics as they have big ego.

According to one of the positive comments: "They need to be like that. It is not a bad thing for a person in their status." For a negative comment: "They talk behind people's back for ego." To a both including comment: "Some academics have egos, but some of them do not have it. It is a difference of generation. All of them are not the same." To a irrelevant/incomprehensible/neutral comment: "My ego is bigger."

\section{The Reasons to Hate Academics - 220 Entries/Comments ${ }^{28}$}

Table 4:

\begin{tabular}{|l|l|l|l|l|l|}
\hline & Positive & Negative & Both Including & $\begin{array}{l}\text { Irrelevant/ } \\
\text { Incomprehensible/ } \\
\text { Neutral }\end{array}$ & Rate \\
\hline $\begin{array}{l}\text { Number of } \\
\text { comments }\end{array}$ & 5 & 29 & 10 & 6 & 50 \\
\hline Percentage & 0,1 & 0,58 & 0,2 & 0,12 & 1 \\
\hline
\end{tabular}

The first comment date: 13.11. 2015

The last comment date: 21.06.2017

For instance, academics are defined as in a positive comment: "People are just talking bad about academics cause of jealousy. That does not mean academics are not good." For a negative comment: "They have no intention to teach something to the students." To a both including comment: "Firstly, I have to say, there are good, helpful, good-humoured academics. However, some of academics are really sick. In a psychological way." For a irrelevant/incomprehensible/neutral comment: "You are really an idiot man!" He/she is not saying who is the man he/she is talking about. It does not make any sense.

\footnotetext{
${ }^{28}$ The links of the analyzed comments are following: https://eksisozluk.com/akademisyenlerden-nefret-etme-nedenleri--4800269? $\mathrm{p}=22$ https://eksisozluk.com/akademisyenlerden-nefret-etme-nedenleri--4800269? $\mathrm{p}=21$ https://eksisozluk.com/akademisyenlerden-nefret-etme-nedenleri--4800269? $\mathrm{p}=20$ https://eksisozluk.com/akademisyenlerden-nefret-etme-nedenleri--4800269? $\mathrm{p}=19$ https://eksisozluk.com/akademisyenlerden-nefret-etme-nedenleri--4800269? $\mathrm{p}=18$ https://eksisozluk.com/akademisyenlerden-nefret-etme-nedenleri--4800269?p=17
} 


\section{Academic Arrests on 15th January 2016 - 320 Entries/Comments ${ }^{29}$}

Table 5:

\begin{tabular}{|l|l|l|l|l|l|}
\hline & Positive & Negative & Both Including & $\begin{array}{l}\text { Irrelevant/ } \\
\text { Incomprehensible/ } \\
\text { Neutral }\end{array}$ & Rate \\
\hline $\begin{array}{l}\text { Number of } \\
\text { comments }\end{array}$ & 26 & 12 & 3 & 9 & 50 \\
\hline Percentage & 0,52 & 0,24 & 0,06 & 0,18 & 1 \\
\hline
\end{tabular}

The first comment date: 15.01 .2016

The last comment date: 18.01.2016

This title was crated on $15^{\text {th }}$ of January 2016 after detaining 27 academics in alleged terror propaganda after they signed a petition.

As we see at the table, positive comments are in the majority with this entry. More than fifty percent of comments are in a positive way. In this time, academics were arrested in Turkey; therefore the comments show that people might have empathized with them. Nevertheless, negative comments come as the second for academics. Thirdly, Irrelevant/Incomprehensible comments follow and finally, both positive and negative comments come about academics.

This entry relatively shows that positive comments get higher in hard circumstances for academics but we cannot say negative comments are few despite to the term either.

For example, academics are defined as in a positive comment: "I have not read the manifesto, but arrest can not be right just cause of fear. It is not fair for them." For a negative comment: "They got what they deserved with arrests." To a both including comment: "I am against to ideas of those academics, but I think arrests are not right thing to do." To a irrelevant/incomprehensible/neutral comment: "The dog barks when it gets scared. I know it is not irrelevant. However i just wanted to say."

\footnotetext{
${ }^{29}$ The links of the analyzed comments are following: https://eksisozluk.com/15-ocak-2016-akademisyen-gozaltilari--5016331?p=32 https://eksisozluk.com/15-ocak-2016-akademisyen-gozaltilari--5016331?p=31 https://eksisozluk.com/15-ocak-2016-akademisyen-gozaltilari--5016331?p=30 https://eksisozluk.com/15-ocak-2016-akademisyen-gozaltilari--5016331?p=29 https://eksisozluk.com/15-ocak-2016-akademisyen-gozaltilari--5016331?p=28, https://eksisozluk.com/15-ocak-2016-akademisyen-gozaltilari--5016331? $\mathrm{p}=27$
} 


\section{The Academic without Ego - 140 Entries/Comments ${ }^{30}$}

Table 6:

\begin{tabular}{|l|l|l|l|l|l|}
\hline & Positive & Negative & Both Including & $\begin{array}{l}\text { Irrelevant/ } \\
\text { Incomprehensible/ } \\
\text { Neutral }\end{array}$ & Rate \\
\hline $\begin{array}{l}\text { Number of } \\
\text { comments }\end{array}$ & 18 & 8 & 13 & 11 & 50 \\
\hline Percentage & 0,36 & 0,16 & 0,26 & 0,22 & 1 \\
\hline
\end{tabular}

The first comment date: 24.06 .2016

The last comment date: 16.12.2016

As we understand from the entry title, it is a positive approach; consequently we see that there is highest level of positive comments. Whereas both including comments come as second, hence we can say that no matter what there is a high negative perception for academics in Turkey.

We see negative comments come for final at the table; though the number of them are close the others. Briefly, on the one hand we see a positive entry and highest positive comments about academics in Turkey; on the other hand negative ones are close to positive ones in spite of the positive entry and positive approach.

For example, according to a positive comment: "He/she is a real science person." For a negative comment: "It is hard to find. There is not." To a both including comment: "It depends to person. There are people have got ego too much and there are people without ego in every job." To a irrelevant/incomprehensible/neutral comment: "It is bellied."

Turkish Style Academic - 790 Entries/Comments ${ }^{31}$

Table 7:

\begin{tabular}{|l|l|l|l|l|l|}
\hline & Positive & Negative & Both Including & $\begin{array}{l}\text { Irrelevant/ } \\
\text { Incomprehensible/ } \\
\text { Neutral }\end{array}$ & Rate \\
\hline $\begin{array}{l}\text { Number of } \\
\text { comments }\end{array}$ & 2 & 31 & 14 & 3 & 50 \\
\hline Percentage & 0,04 & 0,62 & 0,28 & 0,06 & 1 \\
\hline
\end{tabular}

The first comment date: 23.04 .2017

\footnotetext{
${ }^{30}$ The links of the analyzed comments are following:

https://eksisozluk.com/egosu-olmayan-akademisyen--5111935? $\mathrm{p}=14$ https://eksisozluk.com/egosu-olmayan-akademisyen--5111935? $\mathrm{p}=13$ https://eksisozluk.com/egosu-olmayan-akademisyen--5111935? $\mathrm{p}=12$ https://eksisozluk.com/egosu-olmayan-akademisyen--5111935? $\mathrm{p}=11$ https://eksisozluk.com/egosu-olmayan-akademisyen--5111935? $\mathrm{p}=10$ https://eksisozluk.com/egosu-olmayan-akademisyen--5111935?p=9

${ }^{31}$ The links of the analysed comments are following:

https://eksisozluk.com/turk-tipi-akademisyen--5067963?p=78 https://eksisozluk.com/turk-tipi-akademisyen--5067963? $\mathrm{p}=77$ https://eksisozluk.com/turk-tipi-akademisyen--5067963?p=76 https://eksisozluk.com/turk-tipi-akademisyen--5067963?p=75 https://eksisozluk.com/turk-tipi-akademisyen--5067963?p=74
} 
The last comment date: 26.07.2017

For example, according to a positive comment: "They are just like light. I am glad for their existence."

For a negative comment: "They are unnecessary people who are all about ego. Even when you go to his/her room for a signature, they say, 'I am not available right now, so come back tomorrow.' And they do that when they are available." To a both including comment: "They are all about ego. They have no knowledge. They are just trying to humiliate people, because they are in adequate. However, there are rare academics who deserve respect too." To a irrelevant/incomprehensible/neutral comment: "Look at 'power point'."

\section{Academic Who Doesn't Know English - 170 Entries/Comments ${ }^{32}$}

\section{Table 8:}

\begin{tabular}{|l|l|l|l|l|l|}
\hline & Positive & Negative & Both Including & $\begin{array}{l}\text { Irrelevant/ } \\
\text { Incomprehensible/ } \\
\text { Neutral }\end{array}$ & Rate \\
\hline $\begin{array}{l}\text { Number of } \\
\text { comments }\end{array}$ & 2 & 31 & 14 & 3 & 50 \\
\hline Percentage & 0,04 & 0,62 & 0,28 & 0,06 & 1 \\
\hline
\end{tabular}

The first comment date: 21.05 .2017

The last comment date: 27.05.2017

When we look at the table, we see that negative comments are the highest with this entry. More than fifty percent of comments are in a negative way. They intensely criticize the academics do not know English very well, and like we see at the table, there is hardly positive comment (just one) about this entry. Clearly, people cannot tolerate this situation. However, there are both positive and negative comments too, and this show that there are people can empathize with them despite to their negative approach.

For instance, according to a positive comment: "They are the sweethearts. No one have to know English and they must not be have to know English." For a negative comment: "I hope those kind of academics are going to end. An academic must know another language. It is very necessary for them and for students. However academics who do not know English, can not be good ones. No matter what they say, they are can not read international studies and can not make international studies." To a both including comment: "They do not have to learn English. It is not right for everyone, but we have to learn till being a country is the best in science, so they need to know English for the time being. Otherwise, they can not be enough for academy." For a irrelevant/incomprehensible/neutral comment: "The coolest person who wears shoes and bag like a climber."

\footnotetext{
32 The links of the analysed comments are following: https://eksisozluk.com/ingilizce-bilmeyen-akademisyen--3324572? $\mathrm{p}=17$ https://eksisozluk.com/ingilizce-bilmeyen-akademisyen--3324572? $\mathrm{p}=16$ https://eksisozluk.com/ingilizce-bilmeyen-akademisyen--3324572? $\mathrm{p}=15$ https://eksisozluk.com/ingilizce-bilmeyen-akademisyen--3324572?p=14 https://eksisozluk.com/ingilizce-bilmeyen-akademisyen--3324572?p=13 https://eksisozluk.com/ingilizce-bilmeyen-akademisyen--3324572? $\mathrm{p}=12$
} 
An Academic Who Published 270 Articles in 5 Years - 510 Entries/Comments ${ }^{33}$

Table 9:

\begin{tabular}{|l|l|l|l|l|l|}
\hline & Positive & Negative & $\begin{array}{l}\text { Both } \\
\text { Including }\end{array}$ & $\begin{array}{l}\text { Irrelevant/Incomprehensible/ } \\
\text { Neutral }\end{array}$ & Rate \\
\hline & & & & & 10 \\
\hline $\begin{array}{l}\text { Number of } \\
\text { comments }\end{array}$ & 1 & 38 & 1 & 10 & 50 \\
\hline Percentage & 0,02 & 0,76 & 0,02 & 0,2 & 1 \\
\hline
\end{tabular}

The first comment date: 25.03 .2013

The last comment date: 17.01.2017

In this title, $\% 76$ per cent of comments is negative in terms of an academic who published 270 articles in 5 years. He is alleged of plagiarism and repeating previous information in new thesis.

For example, according to a positive comment: "There are some academics who do not read 270 article in 5 years, so you are criticizing the one wrote 270 article in 5 years, thus it is not just right to criticize him. Shame on you guys. That is why academics go to work to another countries." For a negative comment: "If he wrote 270 article in 5 years, it means that he wrote one article in a week, and that shows that he wrote them without reading something. That is a very bad habit and I hope he leave that habit immediately. It is like an endless, bad way. Not a real science." To a both including comment: "I see that as plagiarism, nevertheless I can not say I am not envy him, because of his papers' number. I appreciate him for the number of his papers." To a irrelevant/incomprehensible/neutral comment: "I wonder his end. The last time I know he was committing suicide etc." In this category, another comment says: "Look at the bald man."

\footnotetext{
${ }^{33}$ The links of the analyzed comments are following: https://eksisozluk.com/5-yilda-270-makale-yazan-akademisyen--3201881?p=51 https://eksisozluk.com/5-yilda-270-makale-yazan-akademisyen--3201881?p=50 https://eksisozluk.com/5-yilda-270-makale-yazan-akademisyen--3201881?p=49 https://eksisozluk.com/5-yilda-270-makale-yazan-akademisyen--3201881?p=48 https://eksisozluk.com/5-yilda-270-makale-yazan-akademisyen--3201881?p=47 https://eksisozluk.com/5-yilda-270-makale-yazan-akademisyen--3201881?p=46
} 


\section{Results}

The first two titles which contain maksimum titles are consisted of the all titles $\% 51,46$. These two titles imply negative perception against the academics. These two titles contain averagely $\% 69$ negative perception.

Table 10:

\begin{tabular}{|l|l|l|l|l|l|}
\hline Rank & Title & $\begin{array}{l}\text { Number of } \\
\text { Comments }\end{array}$ & Rate & $\begin{array}{l}\text { Analyzed } \\
\text { Comments }\end{array}$ & $\begin{array}{l}\text { Rate of } \\
\text { Negative } \\
\text { Comments } \\
\text { (Analyzed) }\end{array}$ \\
\hline 1 & Turkish Style Academic / N & 790 & $\begin{array}{l}31,27 \\
\%\end{array}$ & 50 & $62 \%$ \\
\hline 2 & $\begin{array}{l}\text { An academic who } \\
\text { published 270 articles in 5 } \\
\text { years / N }\end{array}$ & 510 & $\begin{array}{l}20,19 \\
\%\end{array}$ & 50 & $76 \%$ \\
\hline & Total: & $\mathbf{5 1 , 4 6}$ & & $\begin{array}{l}\text { Average:69 } \\
\%\end{array}$ \\
\hline
\end{tabular}

This title started on $15^{\text {th }}$ of January 2016 following the arrestments on the same day.

Table 11:

\begin{tabular}{|l|l|l|l|l|l|}
\hline Rank & Title & $\begin{array}{l}\text { Rate of } \\
\text { Positive } \\
\text { Comments }\end{array}$ & $\begin{array}{l}\text { Rate of } \\
\text { Negative }\end{array}$ & $\begin{array}{l}\text { Rate of } \\
\text { Both } \\
\text { Comments }\end{array}$ & $\begin{array}{l}\text { Rate of } \\
\text { Unclear } \\
\text { Comments }\end{array}$ \\
\hline 3 & Academic Arrests / P & 0,52 & 0,24 & 0,06 & 0,18 \\
\hline
\end{tabular}

The first three titles which contain negative comments more than $60 \%$ are carrying a negative meaning in their titles such as an "academic who published 270 articles in 5 years", "Turkish Style Academic", "The Reasons to Hate Academics". 
Table 12:

\begin{tabular}{|l|l|l|ll|}
\hline Rank & Title & $\begin{array}{l}\text { Number } \\
\text { of } \\
\text { Comments }\end{array}$ & $\begin{array}{l}\text { Number of } \\
\text { Analyzed } \\
\text { Comments }\end{array}$ & $\begin{array}{l}\text { Negative of } \\
\text { analyzed } \\
\text { comments }\end{array}$ \\
\hline 1 & $\begin{array}{l}\text { An academic who published } \\
270 \text { articles in 5 years /N }\end{array}$ & 510 & 50 & $76 \%$ \\
\hline 2 & $\begin{array}{l}\text { Academic who doesn't know } \\
\text { English /N }\end{array}$ & 170 & 50 & $62 \%$ \\
\hline 3 & Turkish Style Academic / N & 790 & 50 & $62 \%$ \\
\hline 4 & $\begin{array}{l}\text { The Reasons to Hate Academics } \\
\text { /N }\end{array}$ & 220 & 50 & $58 \%$ \\
\hline 5 & Academic / U & 230 & 50 & $44 \%$ \\
\hline 6 & Ego of Academic / N & 156 & 50 & $42 \%$ \\
\hline 7 & Academic Arrests /U & 320 & 50 & $24 \%$ \\
\hline 8 & $\begin{array}{l}\text { Academic without Ego / P } \\
\text { Total }\end{array}$ & 140 & 50 & $16 \%$ \\
\hline
\end{tabular}

There is no concrete correlation between the age of the titles and number of comments. For example, the third popular title has launched on January 2016 and the oldest title, Academic, is at fifth rank.

All the titles carrying negative meaning have the average rate of positive comments less than $\% 10$. 


\section{Conclusion}

Albert Einstein sad once: "Numerous are the academic chairs, but rare are wise and noble teachers. Numerous and large are the lecture halls, but far from numerous the young people who genuinely thirst for truth and justice." ${ }^{34}$ Being an academic surely requires a long term hard working, fund of academic knowledge, advanced English knowledge and as a result all of these qualities, one may say that they have the goods; even if, many people do not agree with it. When we get back to the Einstein's words, we can say that the part about academics is kind of fountain head of this research. The main purpose of this paper is that seeing how is the perception about academics in Turkey on a popular social media platform, and we wanted to show that with a scientific research. Therefore, academics who work in Turkey may use the results of this paper in a positive way as to improve themselves.

When we categorized the comments as positive, negative, both including and irrelevant/ incomprehensible/neutral, we see that the most featured negative comments are that academics have incontestable personality and big ego, communication problems, plagiarism and insufficient academic productivity. There are almost no positive comments at the titles carrying negative meaning. The title related to academic arrests has most positive comments stand by the academics, and also the title "academic without ego" contains positive comments about the academics who have no ego. The comments which contain both positive and negative meaning indicate mostly that some academics are problematic; however some of them are not. While criticizing majority of academics as stated the negative features, these users believe that few of them are good, the system causes the academic problems and students are problematic or lazy. In this term, we can say that both including comments are more emphatic.

Anonymity can be a very powerful tool to tell something which people cannot generally find the courage to say without anonymity or face to face. That is why, we have chosen eksisozluk.com which is an anonymous social media platform, aims to give freedom of speech to people till a certain degree at least.

In this research, we have analyzed top eight titles in eksisozluk.com. When we type "academic", these titles are "Turkish style academic", "an academic who published 270 articles in 5 years", "academic arrests", "academic", "the reasons to hate academics", "academic who doesn't know English", "ego of academic" and "academic without ego".

When we look at the results of the research, we see that $\% 44$ of the comments are in a negative way about "academic" entry and positive comments' rate are only \%1; \%42 of the comments about the entry of "ego of academic" are negative and $\% 8$ of the comments are positive; the entry of "the reasons to hate academics" includes $\% 58$ negative and $\% 1$ positive comments; $\% 52$ of the comments are positive and \%24 are negative about the entry of "academic arrests on $15^{\text {th }}$ January 2016 " and we see the highest positive rate with this entry; "the academic without ego" gets \%16 negative and $\% 36$ positive comment rate and we see that a positive approach brings more positive comments; "Turkish style academic" entry has \%62 negative and $\% 4$ positive rate of comments; “academic who doesn't know English" entry includes \%62 negative and \%4 positive rate of comments again, and finally, "an academic who published 270 articles in 5 years" entry gets $\% 76$ negative and $\% 2$ positive rate of comments.

We encountered some swearwords, slang and insults in the comments; however these were not the majority. We aimed to give some examples of some comments; however the translation of the dirty words and explanations from Turkish language was almost impossible since the scope of this study. It required mentioning historical and sociological background of the situations and explaining the words in addition to the translation. For this reason, we only made four categories

\footnotetext{
${ }^{34}$ Rowe, David E., and Robert Schulmann. Einstein on Politics: His Private Thoughts and Public Stands on Nationalism ... Princeton,New Jersey: Princeton University Press, 2007.
} 
as mentioned above, and gave the most seen examples. We can advise researchers for future studies to make discourse analyses and compare the perception about academics between Turkey and their countries. They might be useful and original studies too.

In conclusion, when we look at the results of this research, we generally see a negative perception about academics in Turkey. There is a high negative perception almost for each titles except two of them, so we can say that the results show that there is no so much good impression about academics in Turkey on that social media platform (ekşisözlük.com). On the other hand, we see that perception about academics may change in some extreme circumstances like academic arrests on $15^{\text {th }}$ January 2016 , and there is a high positive perception about the entry "academics without ego" too. Nevertheless, even with those two entries which get highest positive comments, still negative perception is not little with them either. As a result, like we have mentioned before, we hope that this study can make a difference for academics to see negative complaints to get better themselves.

\section{References}

Academician Definifition and Meaning /Collins Dictionary. 2010.

https://www.collinsdictionary.com/dictionary/english/academician (accessed 07 28, 2017).

Altbach, Philip G. What counts for academic productivity in research universities? 07 18, 2014. http://www.universityworldnews.com/article.php?story=20140715105656393 (accessed 0809 , 2017).

Arman, Turgut. EkşiSözlük: A Turkish Internet Phenomenon. 08 14, 2006.

http://www.hurriyetdailynews.com/h.php?news=eksi-sozluk-a-turkish-internet-phenomenon2006-08-14 (accessed 12 12, 2010).

Cambridge Dictionary. Meaning of "academician" in the English Dictionary. http://dictionary.cambridge.org/dictionary/english/academician (accessed 07 28, 2017).

Davenport, David. "Anonymity on the internet: why the price may be too high."

Communications of the Acm 45, no. 4 (April 2002): 33.

Eksisozluk.com Traffic, Demographics and Competitors-Alexa. 08 08, 2017. http://www.alexa.com/siteinfo/eksisozluk.com (accessed 08 2017, 10).

Ekşi Sözlük Hakkında Sikça Sorulan Sorular -\#66762977 - ekşi sözlük. 03 10, 2017. https://eksisozluk.com/entry/66762977 (accessed 07 2017, 07).

Ekşi Sözlük Kullanım Koşulları-\#19784395. 01 26, 2016.

https://eksisozluk.com/entry/19784395 (accessed 08 2017, 07).

Froomkin, A. Michael. "From Anonymity to Identification." Journal of Self-Regulation and Regulation, Self-Regulation and Regulation 1 (2015).

Konakay, Gönül, Ali Akdemir, and Banu Ergen. "Investigation Of The Charisma And Intellectuality Effect In Determining A Leadership Model In The Light Of University Students' Interaction With Their Academicians And Parents." Journal of Business Turk 1, no. 7 (2015): 212.

Küçükşen, Kübra. "Perception of gender equality in new media." International Journal of Human Sciences 13, no. 1 (2016): 1286. 
Lattier, Daniel. Why Professors Are Writing Crap That Nobody Reads. 10 26, 2016. http://www.intellectualtakeout.org/blog/why-professors-are-writing-crap-nobody-reads (accessed 08 10, 2017).

Rowe, David E., and Robert Schulmann. Einstein on Politics: His Private Thoughts and Public Stands on Nationalism ... Princeton,New Jersey: Princeton University Press, 2007.

Sarli, Cathy C., and Christopher R. Carpenter. "An overview of measuring academic productivity and changing definitions of scientific impact." Missouri Medicine, 2014: 401.

Scott, Susan, and Wanda J Orlikowski. "Entanglements in Practice: Performing Anonymity Through Social Media." MIS 38, no. 3 (2014): 7.

Türkiye'deki en itibarlı meslekler açıklandı. 02 16, 2017. http://www.yeniakit.com.tr/haber/turkiyedeki-en-itibarli-meslekler-aciklandi-278959.html (accessed 08 10, 2017).

Yusuf Devran'a "ekşi sözlük" üzerinden hakaret ettiği belirlenen ögrrenci Mikail Boz, 3 bin tl manevi tazminat. 10 17, 2014. http://www.haberturk.com/gundem/haber/1000643-dekanahakarete-ceza (accessed 08 25, 2017). 